\title{
Review Article \\ Palaeobiology of Silurian Leptaeninae (Brachiopoda) from Gotland, Sweden
}

\author{
Ole A. Hoel \\ Natural History Museum, University of Oslo, Blindern, P.O. Box 1172, 0318 Oslo, Norway \\ Correspondence should be addressed to Ole A. Hoel; ole_a_hoel@yahoo.no
}

Received 23 August 2013; Accepted 22 October 2013; Published 21 January 2014

Academic Editor: Olev Vinn

Copyright (C) 2014 Ole A. Hoel. This is an open access article distributed under the Creative Commons Attribution License, which permits unrestricted use, distribution, and reproduction in any medium, provided the original work is properly cited.

\begin{abstract}
Leptaenine brachiopods are common and widespread on Gotland. Lepidoleptaena poulseni and Leptaena rhomboidalis retained a functional apical pedicle throughout ontogeny, and both had strong adductor muscles and robust ornamentation, allowing them to occupy shallow water and high energy environments. A pedicle-shortening muscle is present within the pedicle tube of Leptaena rhomboidalis. Leptaena sperion, $L$. depressa visbyensis, and $L$. depressa lata inhabited low energy environments, retaining very slender pedicles. L. depressa depressa and $L$. parvorugata atrophied the pedicle early and then lived ambitopically in deeper water. The presence or absence of the apical pedicle strongly influenced the cardinal process morphology. Leptaenine shells had a small gape. The lophophore was simple, similar to productids and Leptaenoidea. In closed valves, the inner epithelium of leptaenine trails remained exposed to the sea. This was probably important in gas exchange. The life position of pedically attached species was with the disc vertical. Some ambitopic specimens may have retained a similar attitude. Shells of L. depressa depressa and Lepidoleptaena poulseni commonly are encrusted by epibionts, apparently without problems for larger shells. Small shells are shown to have been killed by bryozoan epizoans. Repaired shell damage is rare on the disc but is common along the commisure.
\end{abstract}

\section{Introduction}

The genus Leptaena is one of the most widespread and taxonomically diverse strophomenide brachiopods, with more than 50 named species worldwide and many more occurrences placed in open nomenclature. The temporal distribution is also notable in that the genus extends from the Middle Ordovician (Llanvirn) (e.g., [1]) into the Lower Devonian (Emsian) (e.g., $[2,3]$ ), which amounts to a longevity of about 75 million years. In the Silurian succession of Gotland, Leptaena is a very common component of most brachiopod faunas from the late Llandovery to the Middle Ludlow, after which its role is taken over by the closely related Lepidoleptaena. The taxonomy of these two genera on Gotland has been revised elsewhere [4], following which the recognised species present in the Silurian of Gotland are Leptaena rhomboidalis, Wahlenberg [5]; L. depressa depressa Sowerby, [6]; L. depressa lata, Hoel [4]; L. depressa visbyensis, Hoel [4]; L. sperion, Bassett [7]; L. parvorugata, Hoel [4]; Lepidoleptaena poulseni, Kelly [8]; Lepidoleptaena sp. A and sp. B. In the course of that study several aspects of functional morphology and ecology came to light, which prompted the present paper. Figured specimens belong to the following Swedish institutions: NRM: Swedish Museum of Natural History, Stockholm; PMU: palaeontological collections, Museum of Evolution, Uppsala University; SGU: Geological Survey of Sweden, Uppsala.

\section{External Morphology}

2.1. Shell Form (Figure 1). All leptaenines have a more or less semicircular outline, but often with laterally extended posterolateral margins, called alae. In profile the valves are initially concavoconvex, but later in ontogeny they become parallel and plane. At the margins, both valves often have a small ventral deflection, but then they both geniculate dorsally. The geniculation is usually abrupt $\left(\sim 90^{\circ}\right)$.

Alae. Most specimens of Leptaena and Lepidoleptaena have somewhat expanded alae, but only in Leptaena depressa lata (Figure 1(e)) and some specimens of Lepidoleptaena poulseni (Figure 1(c)) is there great expansion both laterally 


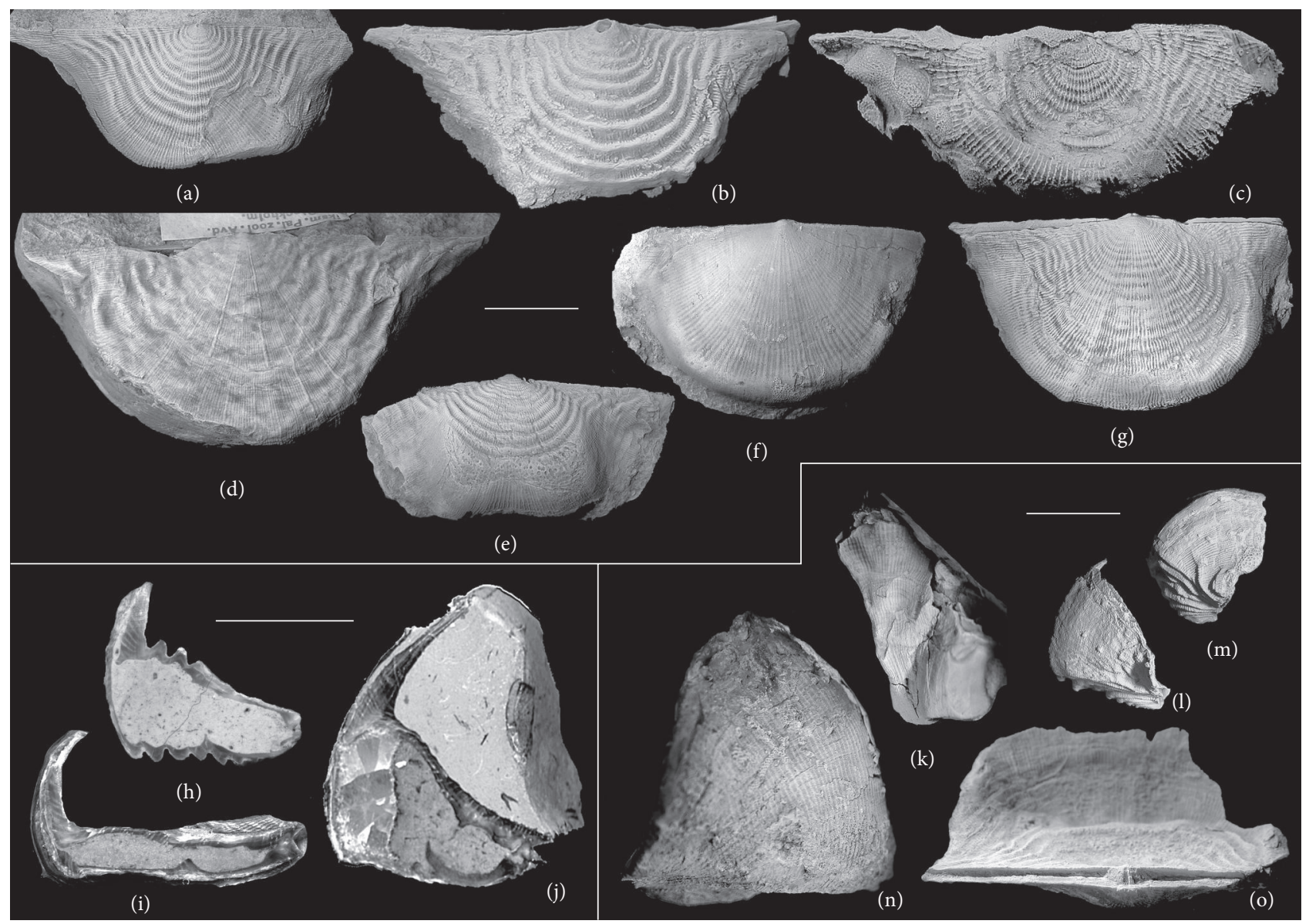

Figure 1: Shell form in Gotland leptaenines. Scale bar $=1 \mathrm{~cm}(=0.5 \mathrm{~cm}$ in detail pictures $)$. (a)-(g): Conjoined valves in ventral view. (a) L. depressa visbyensis. NRM Br32290; Gnisvärd, Tofta parish; Upper Visby Formation. (b) L. rhomboidalis. NRM Br137849; Bals klint; Upper Visby Formation. (c) Lepidoleptaena poulseni. NRM Br121583; Lau Backar, Lau parish; Eke Formation. (d) L. sperion. NRM Br32368; unknown locality, possibly near Visby; Högklint Formation. (e) L. depressa lata. NRM Br32747; Västergarn, Sanda parish. (f) L. parvorugata. NRM Br32641, Follingbo parish. (g) L. depressa depressa. NRM Br112615; Djupvik, Eksta parish; Halla Formation, Djupvik Member. (h)-(j): Conjoined valves in median section. (h) L. rhomboidalis. PMU G1053; unknown locality; large internal volume. (i) L. depressa depressa. PMU G1052; Halla Formation, Fröjel; small internal volume. (j) L. depressa depressa. PMU G1051; Halla Formation, Fröjel; large internal volume. (k)-(o): Conjoined valves in lateral view. (k) L. depressa depressa. NRM Br32557; Visne Myr kanal, Fardhem parish; Hemse Group; note extremely long trail. (l) L. rhomboidalis. NRM Br116187; unknown locality; Upper Visby Formation; flat profile. (m) L. rhomboidalis. NRM Br116186; unknown locality; Upper Visby Formation; Ball-shaped profile. (n) Lepidoleptaena poulseni. NRM Br121581; Gansviken, Grötlingbo parish; Hamra Formation; Very long trail. (o) L. depressa depressa. NRM Br32441; Klintehamn, Klinte parish; Slite Group.

and posteroanteriorly, with the result that the lateral parts of the trail form a "ledge" or "terrace." In other species, the lateral expansion is less, often only developed on one side of the animal and mostly involving only the hinge line and the immediately anterior area. As most adult leptaenines were ambitopic (sensu, Jaanusson [9]; see also [10]) and lost their attachment early in ontogeny, such wide alae are usually interpreted as an adaptation for stability on softer substrates. This is most certainly true for L. depressa lata, which occurs only in the deepest part of the Gotland marine basin, in the southwest area of the outcrop of the Slite Group (see map of species distribution in [4, Figure 12]). On the other hand, similar wide alae are also developed in specimens of the reefdwelling species L. rhomboidalis and Lepidoleptaena poulseni, which both retained a functional pedicle (see [4, Figures 2(J), $8(\mathrm{~A})]$ ). In such a high energy environment, the wide hinge must have been advantageous for another purpose; it might have helped to stabilise the shell in strong currents, as has been suggested for some spiriferids with a wide hinge line [11], allowing the shell to "float" above the substrate. If this interpretation is correct, this would be an interesting adaptation of a preexisting morphology to accommodate a totally different function without much modification. Such interpretations require testing in flume tank experiments.

Trail. The distinctive trail of many leptaenines is usually interpreted as a functional morphology to elevate the commisure above the substrate (e.g. $[12,13])$, with the shell resting on the convex ventral valve. In this attitude, the shell could even be buried within the sediment without the animal dying, as long as the growth of the trail maintained a rate at least equal to the sedimentation rate (see, e.g., [10, page 243]). Another 
possible function was that of separating the feeding currents. Emig [14] considered that the fold and sulcus of living brachiopods make filtering more effective by spatially separating inhalant from exhalant currents and precluding recycling. Analogous solutions have also been described in molluscs, for example, the Pennsylvanian bellerophontacean Knightites multicornutus (see [15, page 248]). The most important effect of the fold and sulcus, however, is to move the position of the inhalant currents to a more anterior position [14]. When the shell anterior is pointing into the current, this produces an increased inflow compared with rectimarginate forms, which have the intake laterally. These factors seem to be borne out by the observation that the volumetric flow rate per unit area is almost twice as great in plicate species than in rectimarginate forms ([14, page 299]). On a firm substrate, the geniculation of many strophomenides may have worked in a comparable way as the plicate commisure of other groups. If the shell were oriented in the conventional way, the trail would lift the anterior part of the commisure higher than the lateral parts and thus separate the exhalant and inhalant currents. In soft substrates, the geniculate shell of a leptaenide would tend to sink, especially anteriorly because of the thickening of the dorsal marginal rim. Thus the entire commisure would lie close to the substrate and the geniculation would only serve to keep the animal from sinking too far. The presence of a trail was therefore advantageous on both hard and soft substrates, and on a hard surface a shell could even survive being flipped over with the dorsal valve lowermost, as suggested by Lescinsky [16], although on a soft substrate the commisure would surely sink and the animal would die.

In several specimens of Leptaena depressa depressa, the trail is extremely long, and in these specimens the anterior commisure is plicate (Figure 1(k), see also [4, Figures 4(S)$4(\mathrm{~T})]$ and [10, text-Figure 3]). This is not observed in specimens with shorter (lower) trails, except in one specimen of L. rhomboidalis (see [4, Figure 2(K)]). As noted by Bassett [10], it is probable that long trailed specimens lived quasiinfaunally and that the plication of the anterior commisure was the only way to separate the inhalant and exhalant currents, because the lateral part of the animal was buried in sediment. The plicate specimen of the normally high-energy species $L$. rhomboidalis may possibly have become detached and transported into softer sediment, which prompted the unusual trail development. Long-trailed specimens are comparatively few in the population and thus represent only the most extreme living conditions. Most other specimens would have lived at or just below the water-sediment interface. Young specimens with a thin and light shell would "float" on the substrate, while older specimens would have usually sunk into the soft sediment with the point of geniculation sinking deepest. The dorsal valve is the thickest, and it is especially thickened at the point of geniculation, with the development of a peripheral rim. Even so, leptaenines also appear to have been able to live in other orientations (see further discussion of this in the section on life position below), and this plasticity of behaviour may have been a reason for the success of the group. Most other ambitopic strophomenides were either relatively flat and thin shelled, "floating" on the substrate (most strophodontids) or with a deeply convexoconcave profile without geniculation, where the shell would have settled into the substrate (e.g., Strophonella and larger plectambonitoideans).

The change in mode of growth at the time of geniculation was fundamental; after this event, the animal can be said to have effectively stopped growing, because the area of the filtration chamber could not become larger. Even so, the animal still had the capacity to increase the internal volume of the shell. This was accomplished in many specimens by ventral growth of the dorsal valve at the peripheral rim, which elevated the dorsal valve, but at the same time rotated the still growing dorsal valve margin posteriorly. To keep the aperture as small as possible, the growing edge of the ventral valve thus had to grow posteriorly as well as dorsally. As the trail grew longer, this resulted in the shell becoming increasingly ballshaped (see Figures 1(l)-1(m) and [4, Figures 2(F)-2(G)]). In specimens where the mantle cavity remained low, the trail was straight or oriented anteriorly.

2.2. Rugae. Rugae are an especially distinct character in leptaenide brachiopods. One of their functions was most probably that of strengthening the shell, which would be advantageous especially in higher energy water and which probably explains the association of several species with precisely this kind of environment. The reef-dwelling $L$. rhomboidalis has shells with extremely deep rugae, a shell thickness of $0.3-$ $0.8 \mathrm{~mm}$ (thickest in the ridge part of the rugae, thinnest in the furrows.) $L$. depressa and $L$. sperion occurs in low energy marlstones, and their shells are $0.2-0.4 \mathrm{~mm}$ thick with quite subdued rugae. L. parvorugata, which occurs only in the presumably deepest environments of the Slite Group, is generally devoid of rugae. The radial sculpture of costellae is developed more or less equally in all these species. Dewing ([17, page 140]) interpreted the rugae of Leptaena and similar brachiopods as functioning as a plough in soft sediments. $\mathrm{He}$ suggested that the animal would have used the pedicle between the valves (see comments on this below) to pull the shell backwards, redistributing sediment with the steep posterior faces of the rugae, and then lets it glide forwards under the pull of gravity on the shallow-angled anterior faces. For this to work, the pedicle would need to be attached to the substrate above the level of the brachiopod and then would only serve to bury the animal. Most sessile animals have a primary need to avoid being buried during excessive sedimentation, and it would seem unnecessary to move even deeper into the sediment. Since most specimens of Leptaena found on Gotland appear to have been current-transported to some degree, a truly infaunal habit also seems unlikely, although some specimens must have lived thus [10].

Rugae may also disclose other aspects of the life of strophomenides. Timms and Brunton [18] inferred growth rate in productides based on numbers of rugae. They suggested that geniculation could have occurred at the onset of sexual maturity, because geniculation occurred at about half adult size; maturity at half adult size seems to be comparable with living brachiopods. They also presented the idea that the number of rugae on productid brachiopods could be related to the growth rate of the animal. They noted that the most likely periodicity in the production of rugae was 
the synodic month, thereby interpreting each ruga to have been produced in one month. In this interpretation the animals that they studied were between 19 and 33 months old at the time of geniculation. If this is applied similarly to leptaenids from Gotland, Leptaena depressa visbyensis from the late Llandovery lower Visby beds reached geniculation in from 5 to 17 months, the Middle Wenlock Leptaena depressa depressa from 5 to 21 months, and the Ludlow Lepidoleptaena poulseni from 4 to 19 months. Why such a fundamental morphological change would occur at seemingly very different times in the life history of different specimens of the same species is unclear, but seems to rule out the idea of sexual maturity; it is unlikely that a specimen could be mature at 4 months. The only published age of sexual maturity in brachiopods that I am aware of is about two years for the Recent terebratulide Calloria (Williams et al., [19, page 95]).

2.3. Phenotypic Variation. As noted by Spjeldnæs [20], the large collections of $L$. depressa depressa from the western outcrop of the Halla Formation (formerly Mulde beds, see [21]) in the Fröjel area demonstrate a clearly expressed dimorphism; type A has a semicircular, anteriorly rounded outline, and a long trail, which can be as long as the disc. Type B has a squared-off disc outline and very short trail. The significance of this dimorphism is as yet unclear, but it seems improbable that it is a sex differentiation, as there are specimens with intermediate morphologies. It may therefore be an ecological effect. Exactly which ecological factors that are involved is difficult to establish without new extensive, wellconstrained collections, since most museum specimens have been collected from scree. They may therefore originate from slightly different stratigraphical levels at the same locality.

Phenotypic variation among Ordovician species of Rafinesquina was studied by Alexander [22], who found that the perimeter/volume ratio (perimeter being the length of the commisure from hinge margin to hinge margin) shows good correlation with the sedimentary environment inferred by other methods. A high ratio suggests a wide, flat shell with a minimum of oxygen-consuming biomass and maximum mantle surface for oxygen uptake and good "snow-shoe" effect keeping the shell "afloat" on soft, muddy substrates, which is where these specimens occur. Conversely, a low ratio indicates a deeper shell with more biomass, weighting the animal into the substrate and keeping it from overturning in stronger currents. A similar relationship may be valid for the specimens of Leptaena from the Fröjel area, but it is not possible to confirm this without further detailed study.

2.4. Life Position. Although concavoconvex shells of strophomenides are found usually with the convex ventral valve uppermost, most workers have advocated a life position with the ventral valve lowermost and the trail vertical, because this would have lifted the commisure above the substrate and minimized the influx of suspended mud particles. In a controversial paper, Lescinsky [16] argued that the life position was the other way round, with the ventral valve on top. In such a position the trail would have worked as an inclined plane and functioning as a sediment trap, hindering coarse suspended material from flowing into the commisure.
In support of this view he studied a large sample of encrusted concavo-convex brachiopods from eleven localities across the USA of Ordovician and Devonian age. In these samples most of the epifauna was preserved on the ventral valve surface, which would be in contact with the substrate in the conventional view. This view has been discussed only briefly by later workers (e.g., $[23,24])$, although it is refuted by the work of Leighton and Savarese [25], who showed that in a convex-upward attitude, the commisure sinks into the substrate if pore water content approaches $50 \%$. Another main argument against Lescinsky's idea is that the convexup position is the most hydrodynamically stable state, to which any dead shell or an individual unable to otherwise right itself would probably end up because of hydrostatic constraints as opposed to biological strategies. The time spent by a dead shell on the surface before burial would generally be sufficient for settlement of encrusters on the ventral valve. Most specimens of Leptaena from Gotland in which the taphonomic attitude of the shell has been observed corroborate this view; they are lying convex-up, and if they are not filled completely with sediment, the lower surface of the geopetal fillings is parallel with the edge of the trail (Figure 2(a)).

From a similar study of conjoined shells of Leptaena and other brachiopods from the western outcrop of the Halla Formation (formerly Mulde beds) on Gotland, Spjeldnæs [20] found that the proportion of encrusters was similar on both valves, which could be interpreted in two ways: (1) the shells could have been exposed on the substrate and then been tumbled around by currents, ending up with epifauna on both valves. This is unlikely because the valves would almost certainly be separated from each other fairly quickly because of the weakly efficient interlocking function of their deltidiodont dentition; (2) they had lived in a vertical position, with the umbo down into the sediment. During fieldwork, I found a specimen of $L$. depressa depressa in this position in the Halla Formation (Mulde Brick clay Member) at Blăhäll, and the geopetal filling in the specimen of Figure 2(b) shows that the shell was buried with its ventral valve more or less vertical. Several specimens of $L$. depressa visbyensis from the Högklint beds (Figure 2(c)) are also buried with their disc vertical. A method by which unattached strophomenides could remain vertical or escape burial was suggested by Dattilo [26], who suggested that the plectambonitoid Sowerbyella was able to move upwards in sediment and orienting itself vertically by valve snapping. A vertical position was probably the normal life orientation in those leptaenines that retained their pedicle throughout life (L. rhomboidalis and Lepidoleptaena poulseni) (see Figure 4).

It is interesting to note that the latter two species developed long trails, even though they were not in danger of being buried in sediment. When the shells are oriented in their supposed life orientation attached to the substrate by a short pedicle, the disc is often seen to have been vertical and the outer portion of the trail horizontal. This probably means that orienting the trail horizontal would impart an advantage to the animal in strong currents. Oriented in this way (as seen in Figure $1(\mathrm{~m})$ ), the shell would present a half-sphere shape towards the current, probably with the 


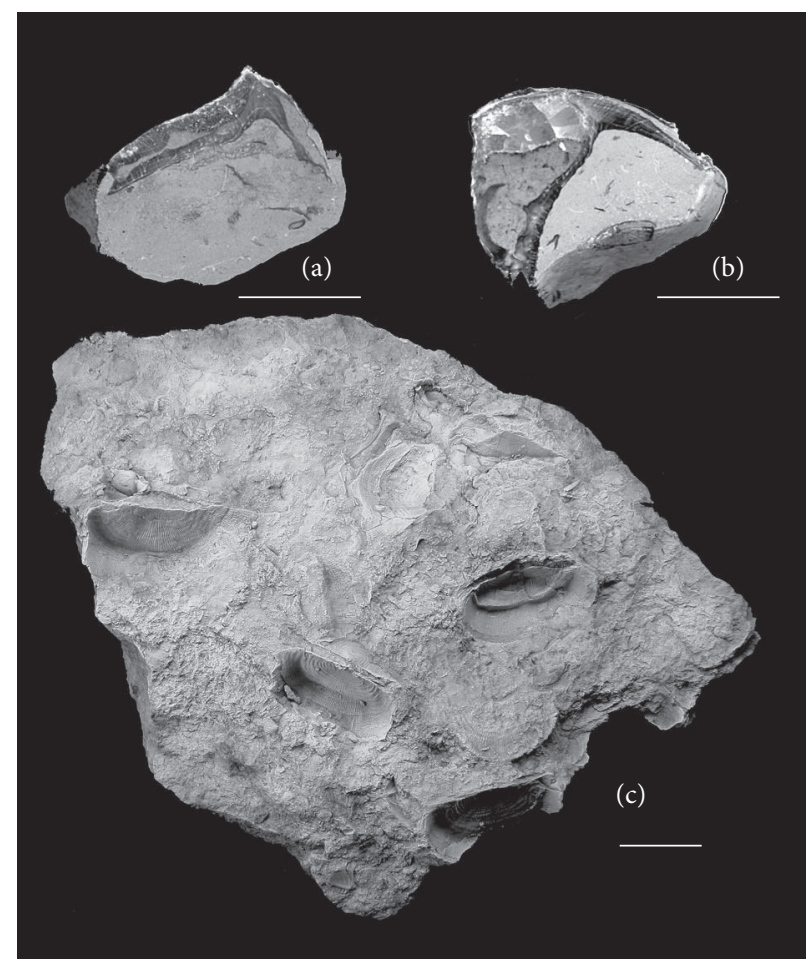

Figure 2: Life position versus postmortem orientation. Scale bar $=1 \mathrm{~cm}(=0.5 \mathrm{~cm}$ in detail pictures). (a) L. depressa depressa. PMU G1055; Halla Formation, Fröjel. Section of conjoined valves buried with commisure horizontal. (b) L. depressa depressa. PMU G1051; Halla Formation, Fröjel. Section of conjoined valves apparently buried with disc in a more or less vertical attitude. (c) L. depressa visbyensis. SGU 9225; Visby Formation Underside of a slab from the Visby Formation showing several individuals of Leptaena depressa visbyensis buried with their umbo pointing downwards. Note that this subspecies had a small, open foramen.

convex side facing into the current. LaBarbera [27] noted that in a unidirectional current, terebratulids orient the shell with their anteroposterior axis normal to the current. Since they have lateral inhalant currents, this would make filtration more effective. In another study [28], I have demonstrated that the cementing strophomenide Leptaenoidea must have had an anteromedial inhalant current. Assuming that the lophophore was essentially similar in Leptaena (see Figure 9), pointing the anteroposterior axis downstream, then gaping would result in eddies behind the commisure. The turbulence would have resulted in particles falling out of suspension, making filtration more effective than having the fast-moving water currents flow through the filtration cavity, maybe damaging the delicate lophophore tentacles in the process.

\subsection{Anchored and Secondarily Free-Lying (Ambitopic) Strate-} gies. As in all marine filter feeding invertebrates (such as bivalves), most living brachiopods have physical stability as a basic requirement. In surface-dwelling bivalves, this is achieved commonly initially by byssal fixation, and later in life by valve thickening (Stanley [29]). Such strategies are probably analogous to those of some ambitopic strophomenide taxa, such as late Palaeozoic productides [12], which had a functional pedicle (or were cementing) in early life, after which they lost their attachment and became thickshelled. In the majority of strophomenide species, however, the loss of attachment did not entail dramatic thickening of the valves, and these relatively thin and light shells must have been in danger of being swept away by currents or buried by sediment. It is therefore not surprising that the greatest diversity of strophomenides is found in relatively low-energy environments, such as the midouter ramp marlstone areas of western Gotland. Even so, many strophomenides thrived in relatively high-energy environments. Of about 15 strophomenide genera present in the Silurian of Gotland, eight occur in high energy (shallow water) environments; four genera were generalists (Leptaenoidea, Brachyprion, Leptostrophia, and Strophonella), occurring in both high-, and lowenergy settings; three genera are found almost exclusively in high energy sediments (Lepidoleptaena, Shaleria, and Strophodonta); and one normally low-energy genus (Leptaena) has a single species (L. rhomboidalis) which is specialized for high energy. Three of the generalists are ambitopic, without any trace of a pedicle in adult shells, while Leptaenoidea is pedically attached in early life and then becomes cementing in high-energy environments or ambitopic in lower-energy environments [28].

In the ambitopic species of Leptaena, thickening of the valves is observed in some specimens, but this is mostly confined to the visceral area and the bounding ridge around the dorsal disc. Otherwise, the valves are quite thin. Together with the long trail, this resulted in the mantle cavity being 
quite deep and the passage from the commisure to the mantle cavity becoming long and narrow, thus probably inhibiting influx of fouling sediment to the lophophore.

Both $L$. rhomboidalis and Lepidoleptaena poulseni have large apical pedicle foramina in their ventral valves throughout ontogeny. L. rhomboidalis occurs in high-energy limestones, predominantly in the Högklint Formation. It retained a functional pedicle throughout life, which grew to be quite thick, as attested by the large foramen, and the shell does not exhibit great thickening, except in the posteromedial area where the visceral mass was situated. Usually it also has a relatively shorter trail than $L$. depressa. The apical foramen is quite similar to that of one group of living lingulates (Discinisca, see [19, Figure 90[5]]), which has only a flat, adhesive pad as an attachment structure. One specimen of Lepidoleptaena poulseni (see [4, Figure 9(A)]) has an impression of the apical pedicle within a bryozoan colony, which apparently grew along and around the pedicle for several $\mathrm{mm}$ outside the shell. The pedicle was therefore longer than the adhesive patch of Discinisca, probably enabling the shell to rotate an appreciable amount, as necessary.

The pedicle of strophomenates was evidently a totally different structure than the pedicle of other rhynchonelliformeans. Rather than being a rod of connective tissue, the strophomenide "pedicle" was probably an outgrowth of the ventral body wall, similar in structure to living lingulates such as Discinisca, in which it contains a large part of the coelom and has a strongly muscular wall ([19, Figures 39, 90[5]]). This was probably the original pedicle structure in the Brachiopoda, which was retained in the Chileata, Obolellata, Kutorginata, and Strophomenata. A wholly new structure was developed in the Rhynchonellata, which originates from the mantle rudiment in larvae ([19, page 60]).

Some specimens of Leptaena rhomboidalis (Figures 3(b)$3(d))$ were cut through vertically at the level of the foramen, showing a section of the tubular chamber connecting the delthyrial cavity and the foramen. On the anteroventral inner surface of this tube there are clear traces of a pedicle adjustor muscle attachment (white arrow in Figure 3(c)). This section of a scar is similar to those preserved in sections through the cardinal processes. A muscle attached here would probably have served to shorten the pedicle, thereby keeping the umbo as close as possible to the substrate. With an attachment close to the anterior wall of the pedicle, retraction of the muscle would have resulted in a rotational moment of the shell towards the ventral valve outer surface. Such a rotational moment could have been necessary to counter water current pressure if the shell presented the ventral valve towards the current (see Figures 4(a)-4(b)). As far as I know, this is the first direct evidence of how the muscular control of the strophomenide pedicle worked. Dewing ([17, pl. 2, Figure 6]) interpreted smooth areas on the dental plates of several strophomenide species from the late Ordovician of Anticosti, Canada, as attachment pads for adjustor muscles, implying a more normal articulate pedicle leaving the shell through the delthyrium. I am not convinced by his arguments; as already shown (Figure 3, see also [17, Figure 5]), the attachment points for muscles are preserved in section as fibres normal to the shell surface, not as layers parallel to it as figured

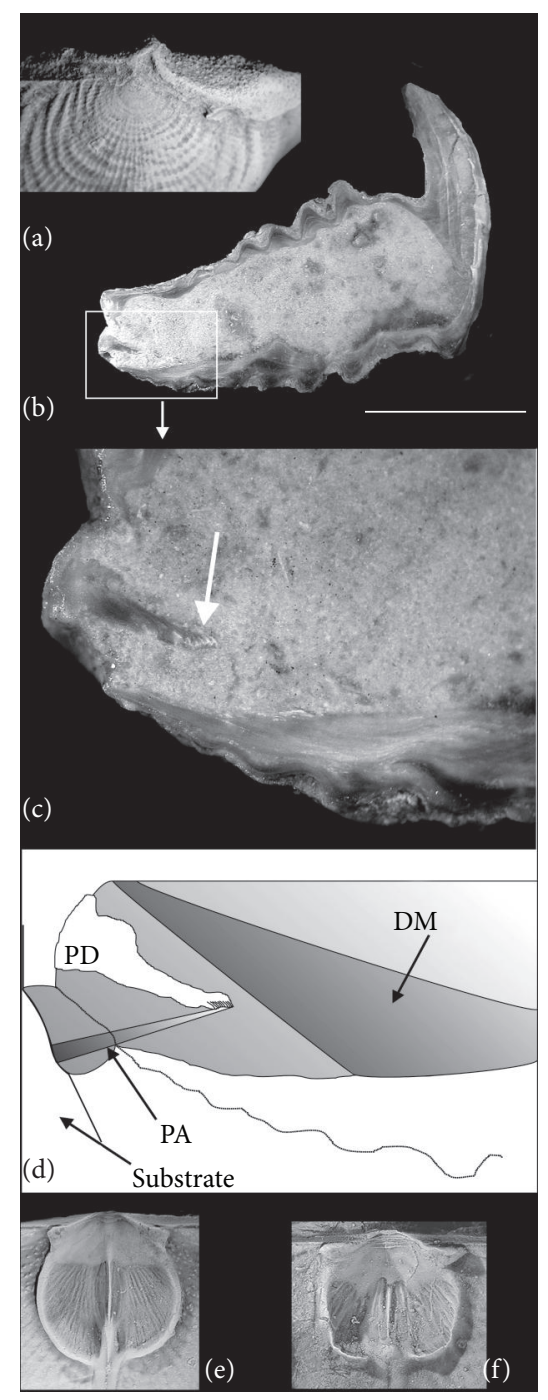

FIGURE 3: (a)-(d): Shape and function of the apical pedicle in attached species. Scale bar $=1 \mathrm{~cm}(=0.5 \mathrm{~cm}$ in detail pictures $)$. (a) Lepidoleptaena poulseni. NRM Br129751; Burgsvik, Öja parish; Hamra Formation; Pedicle length and thickness indicated by bryozoan overgrowth. (b)-(d) L. rhomboidalis. PMU G1054; Visby, Högklint Formation; section through open apical foramen showing scars after attachment of muscles within the pedicle tube (white arrow) and reconstruction of the intrapedicular muscle (PA) attaching to the ventral interarea (PD). DM is the diductor muscles. (e)(f): Internal sealing of the apical foramen in free-lying species. (e) L. parvorugata. NRM Br138049a; Valleviken 1, Rute, Slite Group. (f) L. depressa depressa. NRM Br138045; Mulde Tegelbruk, Fröjel; Halla Formation. Both have covered the apical part of the muscle scars with thick secondary shell material.

by Dewing [17, Figure 10]. If most strophomenides with a small gap between the pseudodeltidium and chilidium had a pedicle, then surely these "adjustor scars" would be preserved in more than an extremely low number of specimens, especially from sequences with extremely good preservation such as those on Anticosti and Gotland. My interpretation of these structures is that they are layers of secondary shell material lining the delthyrial cavity for smooth operation of the diductor muscles. Such layers are often almost nacre-like 


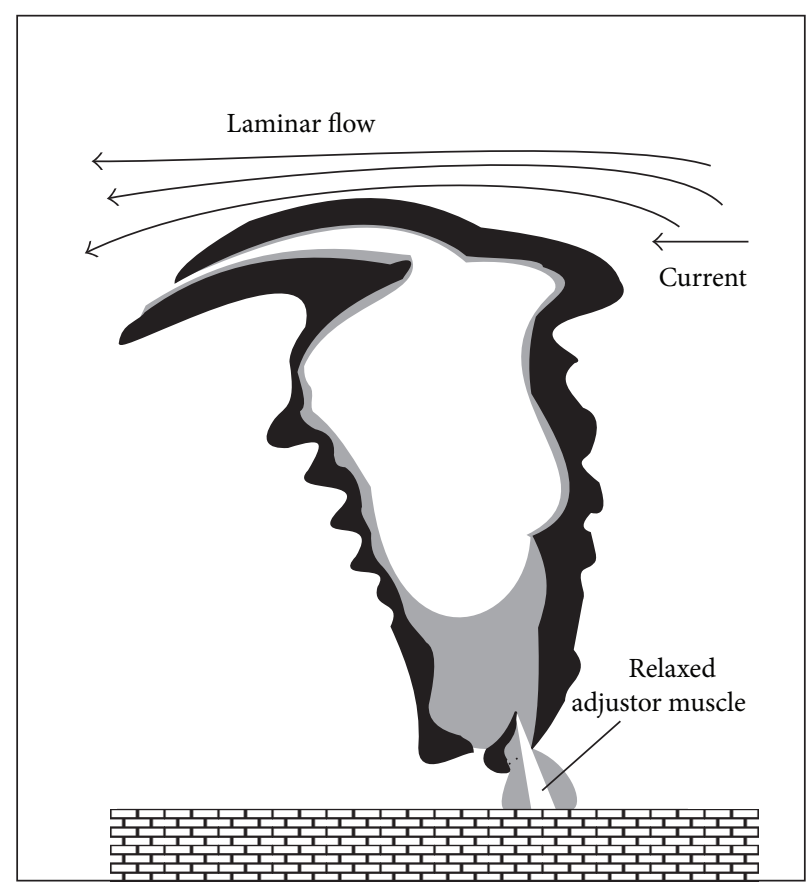

(a)

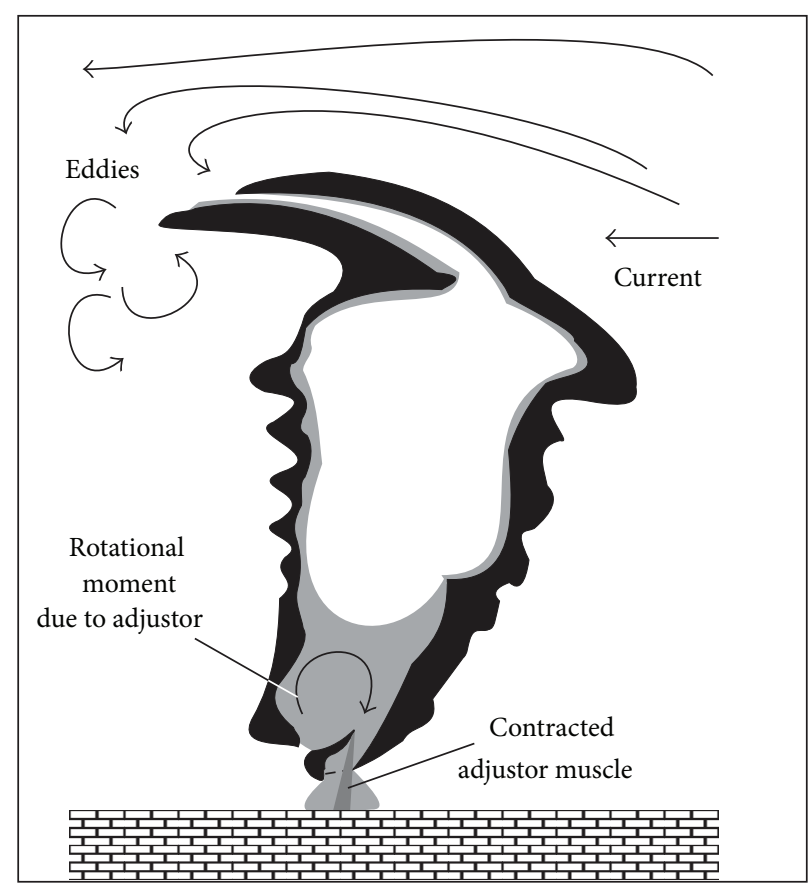

(b)

FIGURE 4: Leptaena rhomboidalis. PMU G1054; Visby, Högklint Formation. Reconstruction of the function of the pedicle retractor muscle inferred from the specimen in Figures 3(b)-3(d). (a) Muscle is relaxed; commisure is oriented down towards the substrate and the current that hits the ventral valve tends to flow past the commisure in a smooth flow. (b) Muscle is contracted; commisure points more upwards and the current becomes disturbed with eddies forming outside the commisure, which makes particle fall out of suspension to be collected by the brachiopod.

in smoothness and are present in most well-preserved Leptaena from Gotland, especially in those that sealed off their interior pedicle tubes early (see Figures 3(e)-3(f)). Dewing [17, Pl. 2, Figure 6] also figures this type of feature (which he interpreted as adjustor scars) in Gunnarella fluctuosa.

2.6. Shell Damage, Predation, and Encrustation. In high energy environments, damage to the shell would have occurred often. When the animal died, the valves would be broken up, but a surprising number of strophomenides show repaired damage, indicating that the animal could survive extensive shell damage. Examples of repaired strophomenide shells can be seen in Alexander ([30] from the late Ordovician of north-central USA), Ebbestad and Högström ([31] from the late Ordovician of central Sweden) and (Dewing [32, pl. 5, Figures 5, 13]; from the late Ordovician of Anticosti, Canada). The incidence of successful shell repair is generally much higher in strophomenides than in other articulated stocks and an explanation for this may be that the close proximity of the two valves probably made damage to the valve edge less catastrophic for strophomenides than for species having more globular shell shapes [23]. Most leptaenids from Gotland display fairly minor damage, especially along the commisure, but in some cases a number of specimens show more extensive repair. Examples of such repair are illustrated in Figure 5. The specimen of L. depressa visbyensis (Figure 5(a)) from the Visby Formation has repaired a substantial injury after having a semicircular portion taken out of the shell, removing about $25 \%$ of the disc. This was probably a result of predation, and it is not improbable that such a shape would be expected from a cephalopod beak. Cephalopods are common on Gotland; Hedström [33] described seven species of Phragmoceras from the Visby Formation alone. Figure 5(b) shows a specimen of Lepidoleptaena poulseni from the Eke Formation, which has lost both lateral portions of the shell, extending to the bounding ridges surrounding the disc. This could also have been a result of predation, but the shallow water, high energy environment in which it occurs, also suggests that the damage could have been a result of strong water buffeting, for example, during a storm. Both these specimens show that when the disc was damaged after the commencement of geniculation, the regrowing mantle was not able to mimic the bordering rugae on the disc; it could only regenerate the growth of the radial ornament of costellae similar to those on the trail. A dorsal valve of Lepidoleptaena poulseni (Figure 5(c)) displays a double disc-bounding ridge, possibly caused by some infection or impairment of growth control.

Evidence of predation is rare among the leptaenids; apart from the specimen noted above, only boring organisms have been noted. Two single valves (not illustrated) of Leptaena depressa depressa from the Halla Formation at Djupvik have been bored through the shell; a ventral valve (SMNH Br108919) has a hole penetrating obliquely through the extramuscular area. This damage was repaired by the brachiopod. A dorsal valve (SMNH Br112648) has been bored vertically 


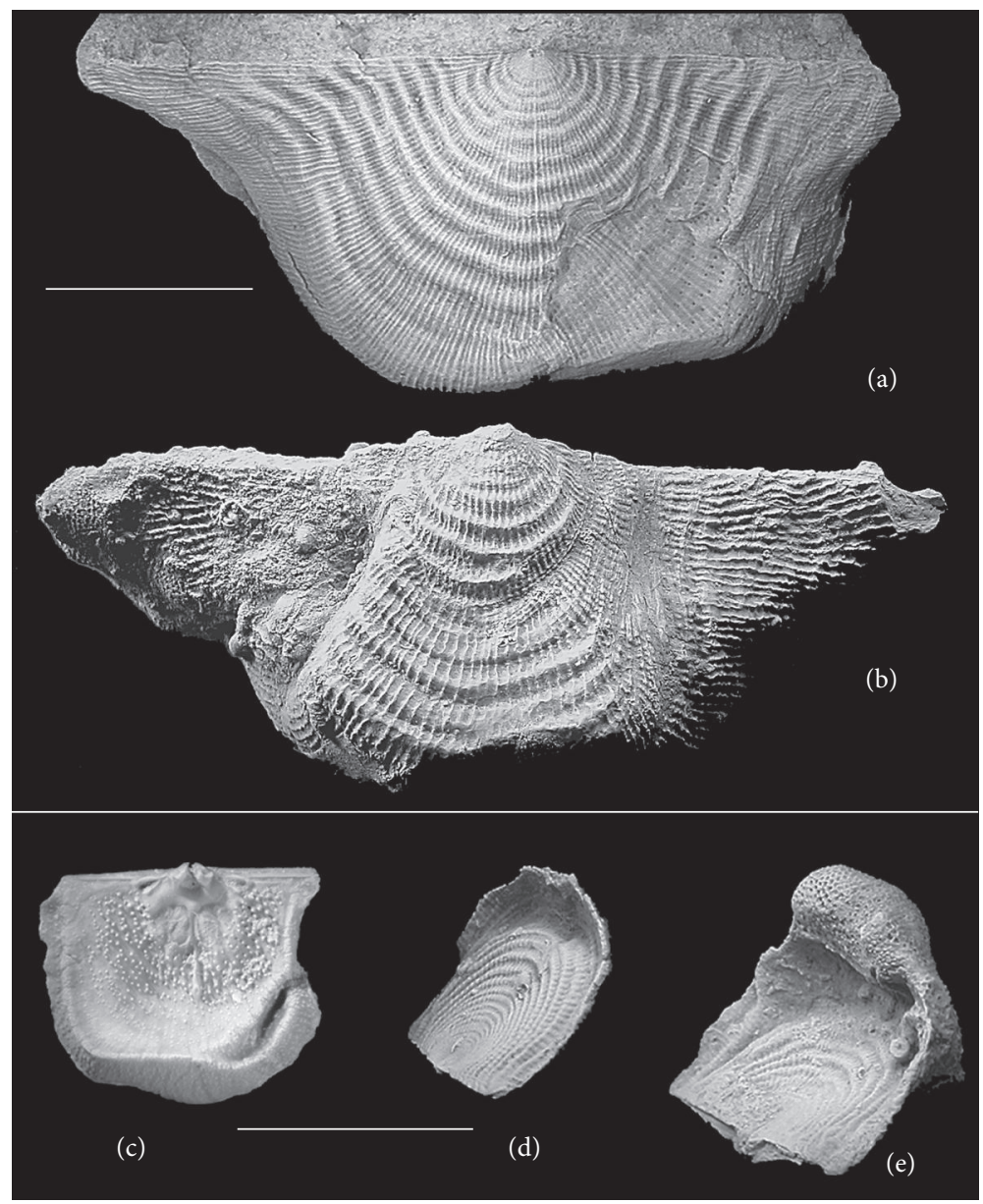

FIGURE 5: Damage and fouling by epibionts. Scale bar $=1 \mathrm{~cm}$ (= $0.5 \mathrm{~cm}$ in detail pictures). (a) L. depressa visbyensis. NRM Br32290; Gnisvärd, Tofta parish; Upper Visby Formation; repaired crescentic wound. (b)-(e): Lepidoleptaena poulseni. (b) NRM Br32699; Lau Backar, Lau parish; Eke Formation; abnormal sculpture on regrown parts of the shell after loss of entire lateral areas on both sides. (c) NRM Br131994; Kättelviken, Sundre parish; Hamra Formation; abnormal growth of dorsal trail on the right side. (d) NRM Br129748; without bryozoan encrustation the trail is low. (e) NRM Br128749; with bryozoan encrustation the trail grew tall in an unsuccessful attempt to escape being overgrown.

through its right adductor muscle. This damage is unrepaired, and the animal thus died from the wound. Alternatively, the shell might have been dead and buried when the boring occurred.

Specimens of Lepidoleptaena poulseni from the Ludlow of Gotland are often encrusted with epifauna. The larger specimens are often covered with oncolithic crusts, usually on the ventral valve. In smaller specimens the surface is more often unencrusted, with the trail often quite low, but when encrusted with bryozoan colonies, the trail becomes long. This may indicate that the brachiopod was trying to outgrow the bryozoan colony as the colonies approach the commisure. The overgrown commisure on such specimens suggests that the competition sometimes killed the brachiopod (Figures 5(d)-5(e)). Large specimens of the same species sometimes have bryozoan epifauna (see Figure 1(c)), but they do not seem to have been troubled by the encrustation. This might indicate a growth rate in large specimens much higher than the growth of the bryozoans. Modern bryozoan colonies have growth rates up to $3 \mathrm{~mm} /$ year, which is about the same as that found in some living brachiopods (Terebratulina retusa initially grows at $4 \mathrm{~mm}$ /year but slows down after three years. It lives for 7 years; [19, page 242]).

The populations of Leptaena depressa depressa from the Fröjel area also show a very large rate of infestation, mostly by bryozoans (about 90\% [20]), where the rate is highest on the trails. Nevertheless, I have not found any specimens that have grown a longer trail because of the infestation. This may be explained by the much larger specimen size (width $\sim 3-4 \mathrm{~cm}$ ) in this sample. Large specimens of Lepidoleptaena poulseni are often heavily encrusted seemingly without any problems, which indicate a refuge from the dangers of infestation above a certain size. This size may be about $15-18 \mathrm{~mm}$ length, as there is a discontinuity in the size distribution in this area (see [4, Figure 11(g)]). A similar discontinuity is found in Leptaena depressa depressa at 10-15 mm length and may be explained in a similar way.

Two small specimens of Lepidoleptaena poulseni from the Hamra beds at Burgsvik (Br129760 and Br129777) have specimens of Petrocrania sp. attached to their dorsal valves, 


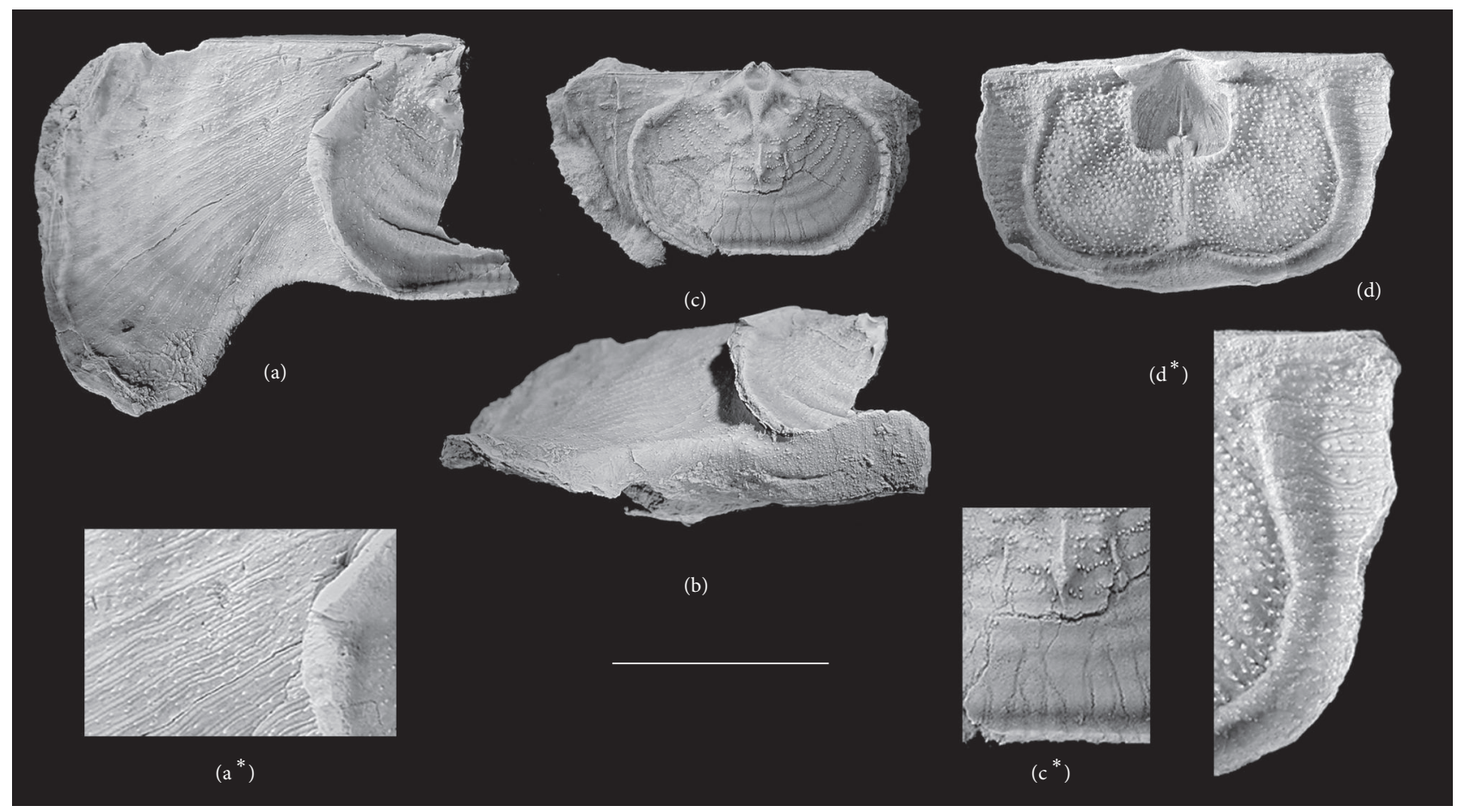

FIGURE 6: Mantle canals. Scale bar $=1 \mathrm{~cm}$ (=0.5 cm in detail pictures). (a)-(b) L. depressa lata. NRM Br134087; Klintehamn, Klinte; strong mantle canals on the extremely large alae. (c) L. depressa lata. NRM Br32745; Västergarn, Sanda; note mantle canals on the disc as well as the trail. (d) L. depressa depressa. NRM Br138045; Mulde Tegelbruk, Fröjel; Halla Formation; rare example of visible mantle canals on the ventral trail.

while the most usual epifauna encrusting this species is Spirorbis.

\section{Internal Morphology}

3.1. Vascular System. In fossil brachiopods the visible trace of the vascular system comprises mantle canal impressions. In living species the canals are predominantly occupied by the gonads. In leptaenines the mantle canals are mostly confined to the trails. According to Williams et al. ([19, page 413]), Leptaena had gonocoelic tissues covering most of the disc area, while the circulation was controlled by the vascula media in the ventral valve and the vascula myaria in the dorsal valve. These are interpreted by these authors to turn laterally along the disc margin, and larger canals $(\sim 0.3 \mathrm{~mm}$ diameter) branch off and continue on the trails to the commisure. In the ventral valves of Leptaena from Gotland, the mantle canals are usually not visible (an exception is shown on Figure 6(d)), but in the dorsal valves they are readily visible on the trail (Figure 6(a)). On the dorsal disc, the canals are usually not developed, but in a specimen of $L$. depressa lata (Figure 6(c)), they can be seen to originate at several locations along the frontal scars (as defined by [8]) and branch repeatedly on the disc before crossing the peripheral rim. This pattern contradicts the interpretation of Williams et al. [19] in that the canals do not originate along the disc margin, but at the anterior body wall. It also shows that the mantle on the disc was not different in organization from that on the trail, although this may indicate that the mantle tissues were thicker on the disc than on the trail, since the mantle canals did not make depressions in the shell material. The large canals on the trail indicate that the mantle tissue was an important component of the circulation system, probably aiding in the uptake of oxygen. When the valves were closed, the mantle cavity was effectively closed by the dorsal disc peripheral ridge, which contacted the inner surface of the ventral valve trail, but even in closely shut shells, the mantle surfaces on the inner surfaces of the dorsal and ventral trails are separated by up to $0.6 \mathrm{~mm}$, which would have continually exposed the mantle tissue to the sea water (Figure 7). The animal could have thus acquired the necessary oxygen and released waste products without opening access to the mantle cavity and the lophophore. The pseudopunctae on the trail are strong and closely approach the opposing valve surface, and they point towards the commisure, so that any particles entering the narrow passage between the valves would have had difficulty entering very far and would have easily been expelled by a quick snapping of the valves (Figure 7).

\subsection{Muscular Systems}

3.2.1. Cardinal Process and Opening of the Shell. In all leptaenines, the strong development of both the notothyrial platform and the cardinal process lobes can be explained probably by the structure and function of the relatively large and heavy dorsal valve. This is especially clear in Lepidoleptaena poulseni, where the large shells often are heavily encrusted, which added significantly to the weight of the dorsal 


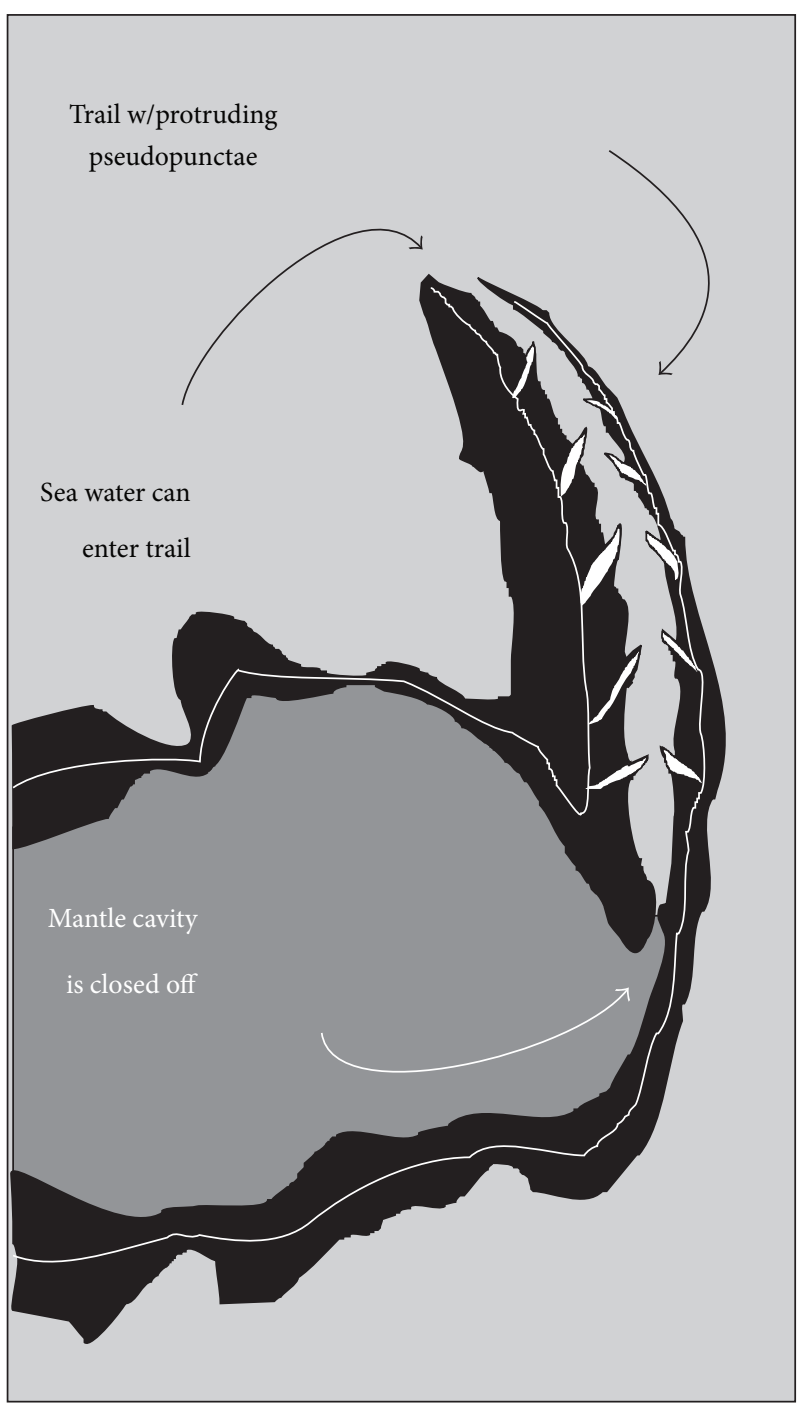

Figure 7: Reconstruction of a closed valve of $L$. depressa depressa showing the gap between the ventral and dorsal trails and how the taleolae (in white) are oriented towards the commisure and act like a sieve.

valve (Figure 1(c)). The ventral valve muscle field is deeply impressed, and also occupies a relatively large part of the disc, emphasising the strength of the diductor muscles. Externally, the base of the cardinal process is massive and is covered by a large chilidium. In Leptaena, the chilidium is much larger than the pseudodeltidium, which is normally very small. The possible opening angle of the shell seems to have been controlled by the large size of the chilidium; during opening, the dorsal valve would have rotated around the teeth until the upper surface of the chilidium contacted the lower edge of the pseudodeltidium. In Leptaena, the pseudodeltidium and chilidium were set a considerable distance posterior to the actual rotation axis of the hinge line. At the same time, the distance between them was very small, and thus the possible angle of rotation was small, probably not more than $\sim 20^{\circ}$. In Lepidoleptaena, the pseudodeltidium is larger than the chilidium, which might indicate a larger gape, but the angle between the two interareas is quite small, so that it would also limit the gap in that genus. This is also the case in many other strophomenides from Gotland (especially the furcitellinids), but in several genera (e.g. Leptaenoidea, Liljevallia, and Mesoleptostrophia), the chilidium is very small and would have rotated under the large pseudodeltidium without contact at any point. These genera could thus have opened their shells at up to an angle of $65^{\circ}$ [28].

The cardinal process lobes are of two distinct forms: (a) divergent and large (Figure 8(e)) and (b) parallel and small (Figure $8(\mathrm{~g})$ ). The occurrence of the two types are correlated with the presence or absence of an open apical foramen. Species which have an open foramen have the type A cardinal process lobes, which not only are divergent but have large, triangular muscle attachment facets facing posteriorly. A wide gap is also present between the cardinal process lobes in these forms, which is interpreted here as allowing space for tissue and muscles associated with the apical pedicle outgrowth. This tissue was presumably located in a cardinal pit, a bowl-shaped depression between and anterior to the cardinal process lobes. The species with type A cardinal process lobes are Leptaena rhomboidalis and Lepidoleptaena poulseni, which have large foramina, and Leptaena sperion, which has a tiny foramen. Type B occurs in $L$. depressa depressa and L. parvorugata, in which the evidently early loss of the pedicle and associated closing of the foramen allowed the cardinal process lobes to grow close together, and they are thus narrow and parallel, with rectangular posterior facets. The cardinal pit is small or absent. L. depressa visbyensis and $L$. depressa lata are intermediate in having a small foramen and large cardinal pit, but their cardinal process lobes are small and parallel. A similar pattern occurs in two species from the Ordovician-Silurian Boundary interval of Anticosti (Dewing [32], e.g., pls 23-24), where specimens of Leptaena quadrilatera Shaler, 1865 has type A cardinal process lobes, a deep cardinal pit, and open foramen, while those belonging to L. cf. valida Bancroft [34] have type B, a small or no cardinal pit, and a sealed foramen.

The reason for these differences may have been that the diductor muscles were most effective when operating as close to the midline of the animal as possible [35]. This is illustrated by Armstrong ([36, Figure 2]), and simple trigonometry shows that more the muscle force is used for actually rotating the shell, the closer the two lines of operation of the diductor muscles are to the midline. This interpretation is also supported by the type B cardinal process being developed whenever a species lost its apical attachment to the substrate and resorbed the pedicle tissue, that is, whenever the larvae settled in low-energy environments where an ambitopic life strategy was possible.

3.2.2. Adductor Muscles. In those species that lived in soft, muddy environments ( $L$. depressa, L. parvorugata), the diductor muscles occupy most of the ventral muscle field, while the adductor scars are relatively small. In high-energy environment species such as L. rhomboidalis and Lepidoleptaena poulseni, the scars of the adductor muscles occupy a much greater proportion of the ventral muscle field, implying that the need to keep the valves closed was more important. 




FIGURE 8: Muscle systems and gape. Scale bar $=1 \mathrm{~cm}$ ( $=0.5 \mathrm{~cm}$ in detail pictures). (a) L. rhomboidalis. NRM Br116301; Stuguklint, Stenkyrka parish; Högklint Formation; open foramen and large chilidium. (b) NRM Br138045 + NRM Br138048; Mulde Tegelbruk, Fröjel; Halla Formation; two valves posed to illustrate the relationship between the muscle scars in the two valves. (c), (d), and (j) L. depressa visbyensis. (c), (j) NRM Br116262; Norderstrand, Visby; Lower Visby Formation; dorsal interior and posterior view of cardinalia. (d) NRM Br137848; Nyhamn, Lummelunda; Lower Visby Formation; ventral interior. (e)-(f) L. sperion. Ansarve, Tofta; Högklint Formation; (e) NRM Brl16273; dorsal muscle field, note cardinal pit and diverging cardinal process lobes (f) NRM Br116271; ventral muscle field, note relatively large adductor scars. (g)-(h) L. parvorugata. Valleviken 1, Rute; Slite Group; (g) NRM Br138049b; dorsal muscle field, note no cardinal pit and small, parallel cardinal process lobes. (h) NRM Br138049a; ventral muscle field, note small adductor scars and secondary shell filling the delthyrial cavity. (i) L. rhomboidalis. NRM Br116161; Östra Vi, Visby; Slite Group; posterior view of cardinal process lobes. (k) Lepidoleptaena poulseni NRM Br121588; Lau Backar, Lau; Eke Formation; dorsal interior showing muscle scars elevated on a platform, and very strong, diverging cardinal process lobes. (1) L. depressa depressa. PMU G1056; probably Mulde tegelbruk, Fröjel; very gerontic specimen with greatly thickened transmuscle ridges.

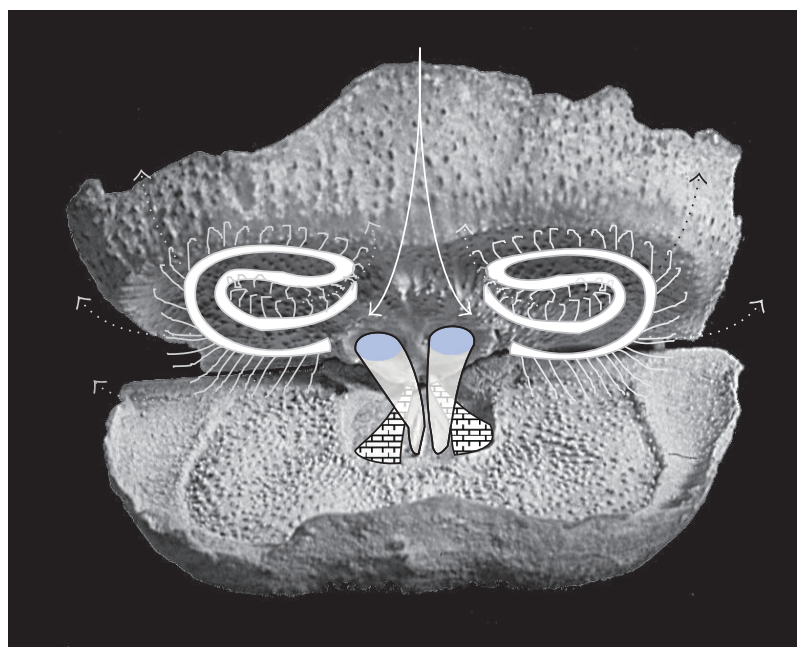

Figure 9: Reconstruction of the muscles and lophophore with feeding currents of $L$. depressa depressa based on Figure 8(b) and the reconstruction of the lophophore of Leptaenoidea in [28].
The shell could have experienced vigorous water current energy, and a shell shaped like Leptaena would be buffeted and rotated on the pedicle. In such circumstances, a tightly closed shell was probably the best survival strategy. Similar strong ventral adductors are developed in L. sperion, even though it is not considered to have been subjected to a very high energy environment. Rather, it is possible that the genetic makeup was more important for this character than the environment. L. sperion is closely related to L. rhomboidalis, and the two species could possibly be ecophenotypes of a single species, as they have very different size and outer morphology, but their interiors are very similar.

The dorsal adductor scars are usually divided by a ridge into anteromedian and posterolateral sectors. In Recent brachiopods (see [19, page 81]), the posterior pair of adductor muscles are long and have striated muscle fibres; they are referred to as the "quick" muscles for fast closing of the valve, while the anterior pair have short, smooth ("catch") muscle fibres, which close the valves tightly and can remain contracted for a long time. This anterior position of the catch 
muscles results in them having much stronger leverage for holding the valves together. Although the dorsal adductor scars of leptaenines are divided, it is not clear whether the same division of labour can be inferred. Although the scarseparating ridge is set at $\sim 45^{\circ}$ to the hinge line in Leptaena, most of the anteromedian pair of muscles would not strictly be anterior to the quick muscles, and in gerontic specimens they are not separated at all (Figure $8(1)$ ). The short distance between the valves also did not necessitate long tendons between the muscles and their ventral attachment.

3.3. Lophophore Anatomy and Feeding Method. The configuration of the lophophore in Leptaena is unknown, but several ventral valves of $L$. depressa have traces that may throw some light on its structure. They have coiled, raised ridges (Figure 6(d), see also Davidson [37], pl. 39, Figure 15), not unlike the ridges in the dorsal valve of productides (see [38]), and also in the cementing strophomenide Leptaenoidea [39] from Gotland [28]. If the lophophore of Leptaena was suspended from the dorsal mantle just above this ridge (there is no preserved ridge on the inner surface of the dorsal valves of Leptaena itself), the shape could be reconstructed as quite similar to that of Leptaenoidea. As already noted, leptaenines could not open their shells very widely, so the anterior inhalant current would probably be more important than in Leptaenoidea, while the exhalant current would probably exit the shell quite far posterolaterally, probably just anterior to the posterolateral margins of the shell.

This feeding method would be quite similar to the method used by Recent brachiopods, which produce feeding currents by the rhythmic motion of cilia on the tentacles and the mantle surface. The tentacles are similar in size throughout life; in living forms there are about 20 tentacles per $\mathrm{mm}$ of lophophore, and the amount of food particles trapped is proportional to the absolute number of tentacles [40]. In small specimens of living species, the lophophore is simple, comprising a one-dimensional ring or a schizolophe, with a small number of tentacles. As the animal grows larger, the volume of the animal grows faster than the area of tentacles, and the need to increase the number of tentacles thus becomes greater and greater. Therefore the lophophore must be coiled in different ways, primitively as two spirals (vertical or horizontal). In the most successful modern group, the Terebratulida, the coiled lophophore first has a wide sweep along the lateral margins, then it swings backwards anteriorly and then into a medial vertical spiral. This is the most effective way of filling the available space in the mantle cavity. In most strophomenides, the valves remained close together during ontogeny, and even large specimens usually had a mantle cavity of small volume. The preserved lophophore traces seen in some genera (such as Leptaenoidea, Leptaenisca, Christiania, Eoplectodonta, and many productides) appear to indicate that the lophophore did not develop to more than a relatively small schizolophe. Because there would not be many tentacles present on the short brachia, the ciliary pumping action alone might not have been sufficient for adult (or in any case large) strophomenides [41]; it would suffice only in specimens up to a few $\mathrm{mm}$ in length. Zorn's alternative view, following Rudwick $[12,42]$, is that the valves opened and closed continuously during feeding. Due to the small interior volume when the valves were closed, opening the shell would draw water into the mantle cavity, where the lophophore could extract food particles. When the valves closed again, practically all the water would be expelled, so that the next time it opened its valves, new and undepleted water would enter the mantle cavity. This method would have made the water exchange more complete but would not then have made the extraction of particles from the water more effective because that would still depend on the number of tentacles. In addition, these "flapping valves" would need diductor muscles capable of repeated and fairly rapid movement to lift the dorsal valve sufficiently quickly to create the inflow. Modern brachiopods, even lingulides and craniides, have neither fast diductors nor adductor muscles capable of often repeated effort, so if the strophomenides used this system, a radically different muscle physiology must be inferred.

As an alternative, Westbroeck et al. [43] suggested that the mantle surface could have been effective in gas exchange, as I have already noted for the trails, and even in collecting dissolved nutrients directly from the water. In this scenario the reduced lophophore would only be involved in the largeparticle catching. The mantle surface area of strophomenides was relatively larger than in other brachiopods because it would follow the surface of the protruding taleolae, which may support this hypothesis. Westbroeck et al. [43] also suggested that the ciliated mantle surface could have acted as a particle filtration device in its own right, but then for extracting mud particles and transporting them to the mantle edge. This would make the filtration by the lophophore more effective and make it possible for the animal to live in more turbid water than other brachiopods.

\section{Conflict of Interests}

The author declares that there is no conflict of interests regarding the publication of this paper.

\section{Acknowledgments}

This paper has benefited from helpful discussions and reviews by M. G. Bassett, National Museum of Wales; L. Holmer and J. S. Peel, both from Uppsala University. Facilities were provided by the Palaeobiology Program, Institute of Earth Sciences, Uppsala University. Technical support from J. O. R. Ebbestad, Uppsala University, is greatly appreciated.

\section{References}

[1] N. Spjeldnæs, The Middle Ordovician of the Oslo Region, Norway. 8. Brachiopods of the Suborder Strophomenida, vol. 37 of Norsk Geologisk Tidsskrift, 1957.

[2] C. W. Merriam, Paleontology and Stratigraphy of the Rabbit Hill Limestone and Lone Mountain Dolomite of Central Nevada, vol. 808 of US Geological Survey Professional Paper, 1973.

[3] A. Williams, S. J. Carlson, C. H. C. Brunton et al., Treatise on Invertebrate Paleontology. Part H: Brachiopoda, vol. 2-3, Geological Society of America, 2000. 
[4] O. A. Hoel, "Silurian Leptaeninae (Brachiopoda) from Gotland, Sweden," Paläontologische Zeitschrift, vol. 79, no. 2, pp. 263-284, 2005.

[5] G. Wahlenberg, Petrificata Telluris Svecanae, Nova Acta Regiae Societatis Scientiarium Upsaliensis 8, 1821.

[6] J. D. C. Sowerby, The Mineral Conchology of Great Britain, Meredith, London, UK.

[7] M. G. Bassett, The Articulate Brachiopods from the Wenlock Series of the Welsh Borderland and South Wales: Part 4, Monographs of the Palaeontographical Society, 1977.

[8] F. B. Kelly, "Silurian Leptaenids (Brachiopoda)," Palaeontology, vol. 10, pp. 590-602, 1967.

[9] V. Jaanusson, "Ecology and faunal dynamics", in Lower Wenlock Faunal and Floral Dynamics - Vattenfallet Section, Gotland, V. Jaanusson, S. Laufeld, and R. Skoglund, Eds., vol. 762 of Sveriges Geologiska Undersökning C, pp. 253-294, 1979.

[10] M. G. Bassett, "Life strategies of Silurian brachiopods," Special Papers in Palaeontology, vol. 32, pp. 237-263, 1984.

[11] F. G. Blight and D. F. Blight, "Flying spiriferids: some thoughts on the life style of a Devonian spiriferid brachiopod," Palaeogeography, Palaeoclimatology, Palaeoecology, vol. 81, no. 1-2, pp. 127-139, 1990.

[12] M. J. S. Rudwick, Living and Fossil Brachiopods, Hutchinson University Library, London, UK, 1970.

[13] R. P. Richards, "Autecology of Richmondian brachiopods (late Ordovician of Indiana and Ohio)," Journal of Paleontology, vol. 46, pp. 386-405, 1972.

[14] C. C. Emig, "Functional disposition of the lophophore in living Brachiopoda," Lethaia, vol. 25, no. 3, pp. 291-302, 1992.

[15] J. S. Peel, "Systematics, ontogeny and functional morphology of Silurian trilobed bellerophontacean gastropods," Bulletin of the Geological Society of Denmark, vol. 23, pp. 231-264, 1974.

[16] H. L. Lescinsky, "The life orientation of concavo-convex brachiopods: overturning the paradigm," Paleobiology, vol. 21, no. 4, pp. 520-551, 1995.

[17] K. Dewing, "Hinge modifications and musculature of strophomenoid brachiopods: examples across the OrdovicianSilurian boundary, Anticosti Island, Quebec," Canadian Journal of Earth Sciences, vol. 38, no. 2, pp. 125-141, 2001.

[18] A. E. Timms and C. H. C. Brunton, "Growth rates and periodicity in Antiquatonia and Plicatifera, lower carboniferous productacean brachiopods," in Proceedings of the 2nd International Brachiopod Congress, Brachiopods through Time, D. I. Mackinnon, D. E. Lee, and J. D. Campbell, Eds., pp. 41-47, Balkema, Dunedin, New Zealand, 1991.

[19] A. Williams, S. J. Carlson, C. H. C. Brunton et al., Treatise on Invertebrate Paleontology. Part H: Brachiopoda, vol. 1, Geological Society of America, 1997.

[20] N. Spjeldnæs, "Epifauna as a tool in autecological analysis of Silurian brachiopods," Special Papers in Palaeontology, vol. 32, pp. 225-235, 1984.

[21] M. Calner and L. Jeppsson, "Carbonate platform evolution and conodont stratigraphy during the middle Silurian Mulde Event, Gotland, Sweden," Geological Magazine, vol. 140, no. 2, pp. 173203, 2003.

[22] R. R. Alexander, "Phenotypic lability of the Brachiopod Rafinesquina alternata (Ordovician) and its correlation with the sedimentologic regime," Journal of Paleontology, vol. 49, pp. 607-618, 1975.

[23] R. R. Alexander, "Function of external skeletal characteristics of articulate brachiopods," in Functional Morphology of the
Invertebrate Skeleton, E. Savazzi, Ed., pp. 371-398, Wiley \& Sons, New York, NY, USA, 1999.

[24] R. R. Alexander, "Functional morphology and biomechanics of articulate brachiopod shells," Paleontological Society Papers, vol. 7, pp. 145-169, 2001.

[25] L. Leighton and M. Savarese, "Functional and taphonomic implications of Ordovician strophomenide brachiopod valve morphology," in Brachiopods, P. Copper and J. Jin, Eds., pp. 161168, A. A. Balkema, Rotterdam, The Netherlands, 1996.

[26] B. F. Dattilo, "A new angle on strophomenid paleoecology: trace-fossil evidence of an escape response for the plectambonitoid brachiopod Sowerbyella rugosa from a tempestite in the Upper Ordovician Kope Formation (Edenian) of Northern Kentucky," Palaios, vol. 19, no. 4, pp. 332-348, 2004.

[27] M. LaBarbera, "Brachiopod orientation to Water movement: functional morphology," Lethaia, vol. 11, pp. 67-79, 1978.

[28] O. A. Hoel, "Cementing strophomenide brachiopods from the Silurian of Gotland (Sweden): morphology and life habits," Geobios, vol. 40, no. 5, pp. 589-608, 2007.

[29] S. M. Stanley, Relation of Shell form to Life Habits of the Bivalves (Mollusca), Geological Society of America Memoir 125, 1970.

[30] R. R. Alexander, "Resistance to and repair of shell breakage induced by durophages in Late Ordovician brachiopods," Journal of Paleontology, vol. 60, no. 2, pp. 273-285, 1986.

[31] J. O. R. Ebbestad and A. E. S. Högström, "Shell repair following failed predation in two Upper Ordovician brachiopods from central Sweden," Geologiska Föreningens I Stockholm Förhandlingar, vol. 122, no. 3, pp. 307-312, 2000.

[32] K. Dewing, Late Ordovician and Early Silurian Strophomenid Brachiopods of Anticosti Island, Québec, Canada, vol. 17, Palaeontographica Canadiana, 1999.

[33] H. Hedström, Über die Gattung Phragmoceras in der Obersilurformation Gotlands, vol. 15 of Sveriges Geologiska Undersoökning, 1917.

[34] B. B. Bancroft, Welsh Valentian Brachiopods and the Strophomena Antiquata Group of Fossil Brachiopods, Privately printed, Mexborough, UK, 1949.

[35] V. Jaanusson and H. Neuhaus, "Mechanism of the diductor muscles in articulate brachiopods," Stockholm Contributions in Geology, vol. 13, pp. 1-8, 1965.

[36] J. Armstrong, "Analysis of the function of the diductor muscles in articulate brachiopods," Neues Jahrbuch für Geologie und Paläontologie, vol. 11, pp. 641-654, 1968.

[37] T. Davidson, British Fossil Brachiopoda, vol. 3, part 7, no. 4, Monograph of the Palaeontological Society, London, UK, 1871, index and appendix for volume III, and general index to volume I-III.

[38] C. H. C. Brunton, "The functional morphology and palaeoecology of the Dinantian brachiopod Levitusia," Lethaia, vol. 15, pp. 149-167, 1982.

[39] H. Hedström, Ueber Einige mit der Schale Befestigte Strophomenidae aus dem Obersilur Gotlands, vol. 276 of Sveriges Geologiska Undersökning C, 1917.

[40] F. Surlyk, "Life habit, feeding mechanism and population structure of the Cretaceous brachiopod genus Aemula," Palaeogeography, Palaeoclimatology, Palaeoecology, vol. 15, no. 3, pp. 185-203, 1974.

[41] H. Zorn, "Form und funktion von Gehäuse und Lophophor der Strophomenida (Brachiopoda)," Neues Jahrbuch für Geologie und Paläontologie, pp. 49-64, 1979. 
[42] M. J. S. Rudwick, "The feeding mechanism of the Permian brachiopod Prorichthofenia," Palaeontology, vol. 3, pp. 450-471, 1961.

[43] P. Westbroeck, J. Yanagida, and Y. Isa, "Functional morphology of brachiopod and coral skeletal structures supporting ciliated epithelia," Paleobiology, vol. 6, pp. 313-330, 1980. 

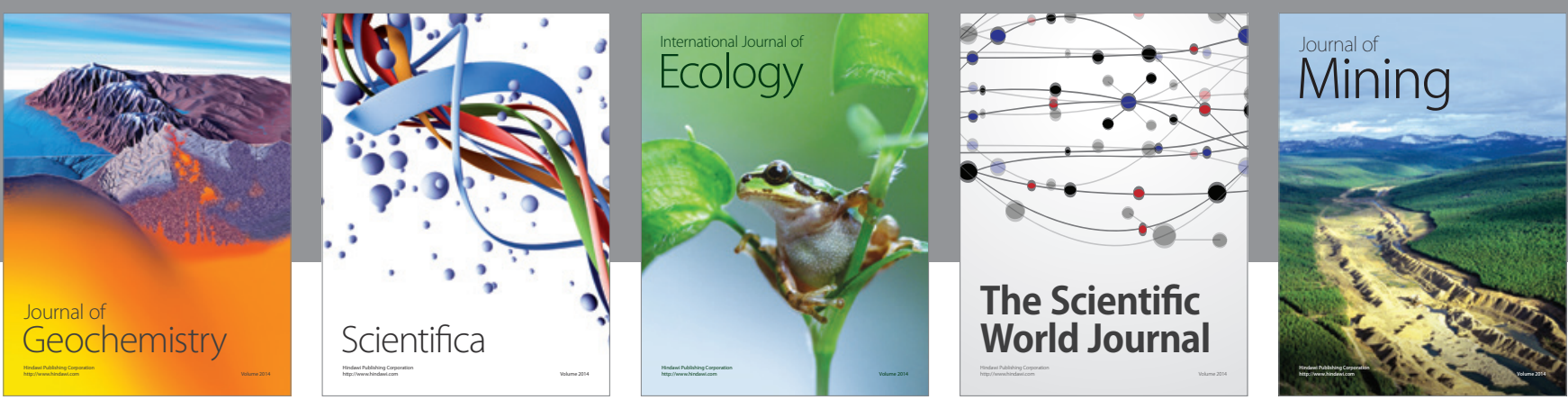

The Scientific World Journal
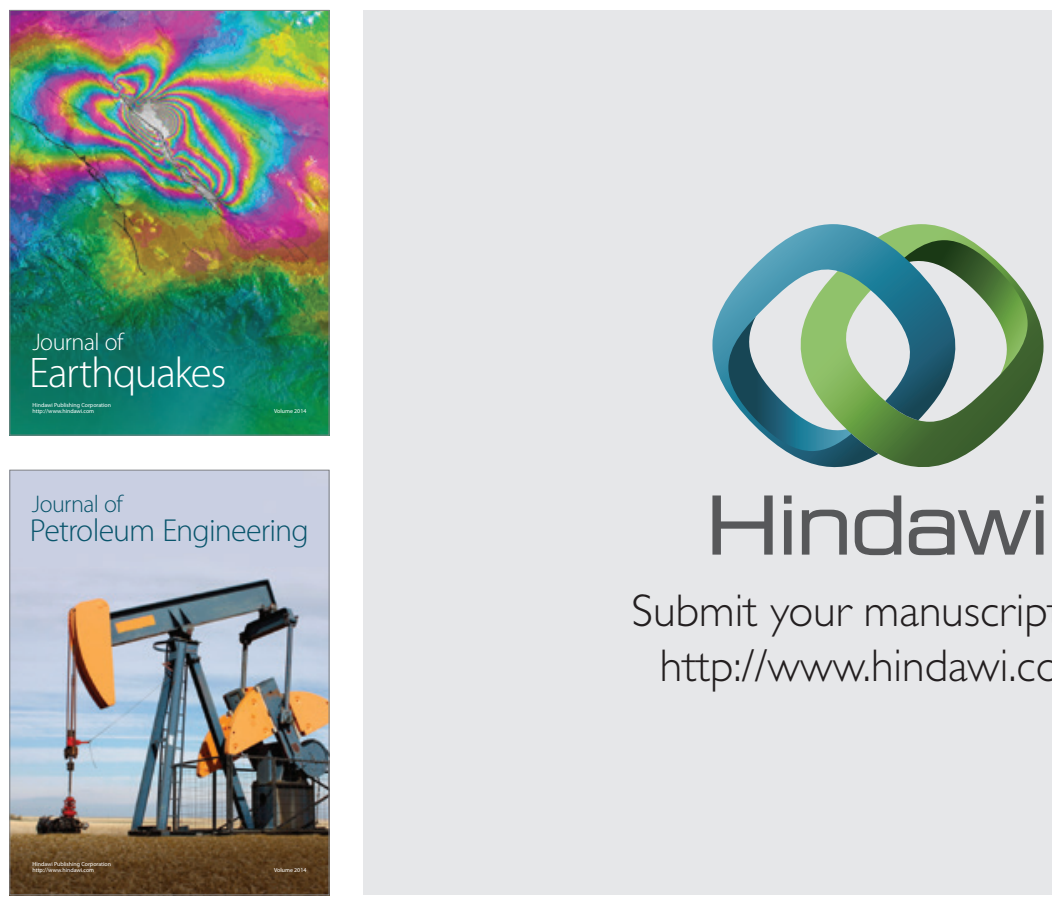

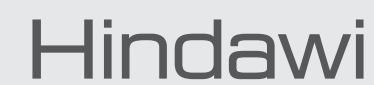

Submit your manuscripts at

http://www.hindawi.com
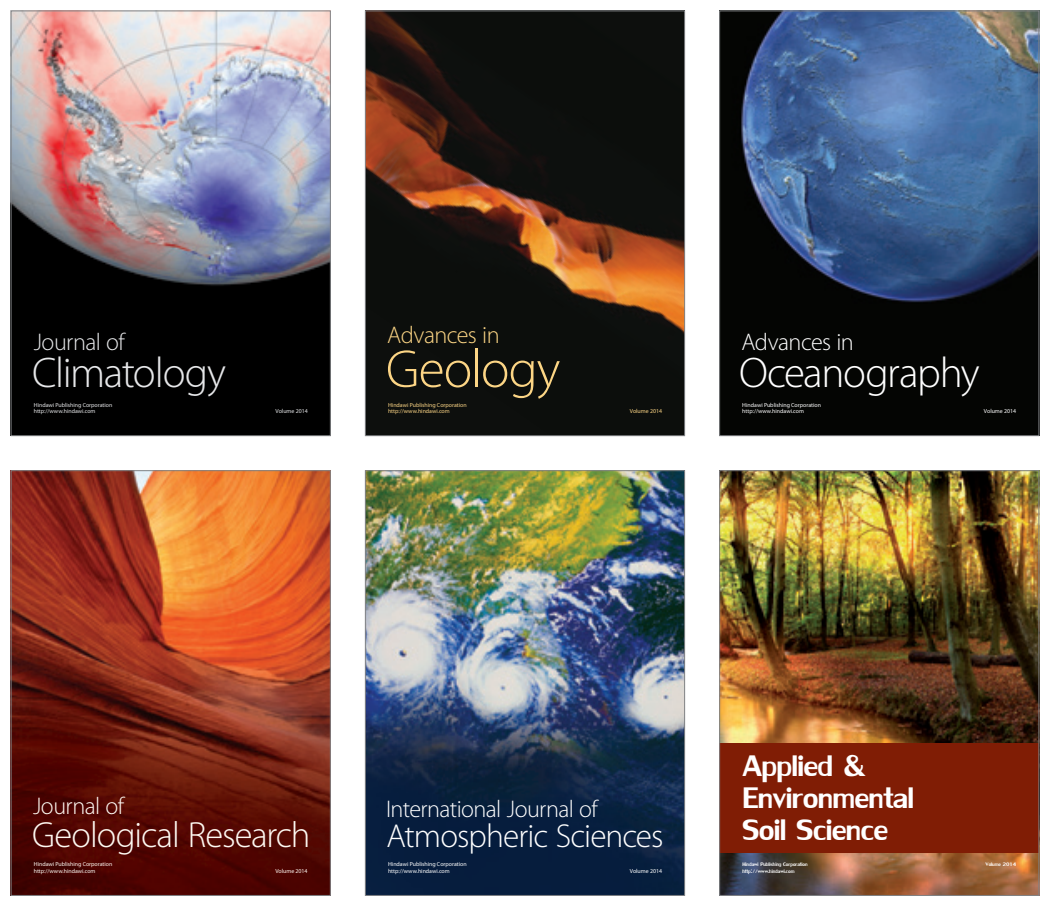
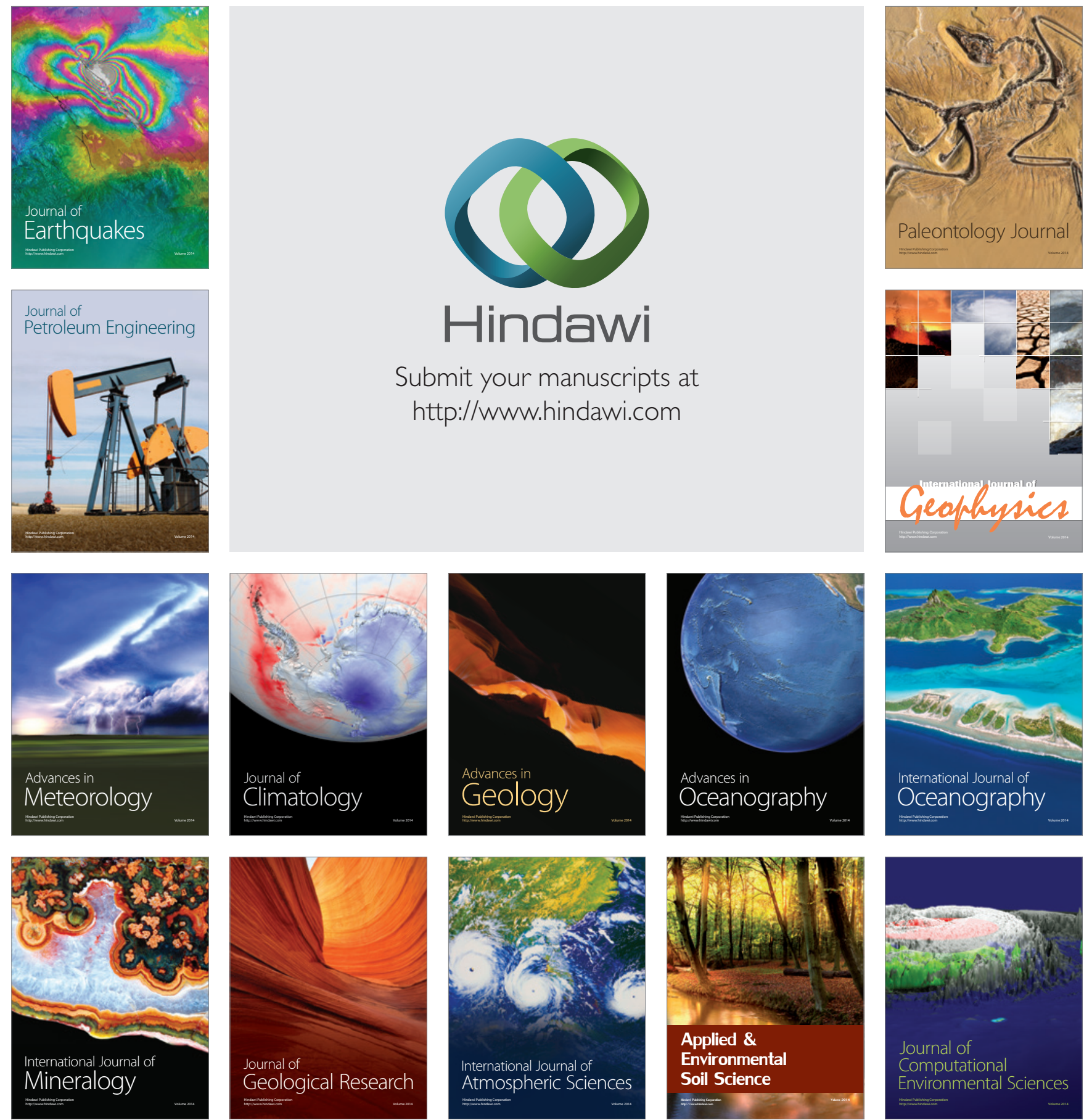